\title{
Digital Additive Manufacturing: A Paradigm Shift in the Production Process and Its Socio-economic Impacts
}

\author{
Ed Forrest ${ }^{1} \&$ Yong $\mathrm{Cao}^{1}$ \\ ${ }^{1}$ College of Business and Public Policy, University of Alaska Anchorage, Anchorage, AK, USA \\ Correspondence: Yong Cao, College of Business and Public Policy, University of Alaska Anchorage, Anchorage, \\ AK 99508, USA. Tel: 1-907-786-4176. E-mail: ycao@uaa.alaska.edu
}

Received: August 23, 2013

Accepted: October 12, 2013 Online Published: October 15, 2013

doi:10.5539/emr.v2n2p66

\author{
URL: http://dx.doi.org/10.5539/emr.v2n2p66
}

\begin{abstract}
The most simple and sweeping proposition with respect to 3D printing is that it will change everything because it can print everything. 3D printing (also known as digital additive manufacturing) is a key driver behind the on-going paradigm shift from $20^{\text {th }}$ century industrial production and economics to the $21^{\text {st }}$ century post-industrial order defined by open-source collboration, intelligent, nanoscale and bio technologies. This paper examines four distinct characteristics of $3 \mathrm{D}$ printing that define and predict its revolutionary ramifications on manufacturing processes and the geo-economic contours of global trade. Digital additive manufacturing renders the established manufacturing process obsolete. 3D printing's rapid diffusion is a consequence of its vast assortment of applications being freely available on open crowd-sourced websites. When one combines the ability and convenience of producing one's own customized goods with the savings accrued through the elimination of labor, re-tooling, assembly, shipping and inventory carrying costs, the consequences are most ominous for any and all engaged in traditional manufacturing and dependent on the relative cost-efficiencies of out-sourcing. 3D printing not only renders factories obsolete but threatens whole country's economies as production is taken up by the consumer and distribution is de-globalized.
\end{abstract}

Keywords: 3D printing, additive manufacturing, direct digital manufacturing

\section{Introduction}

Periodically, a new technology comes along wherein its dissemination completely redefines the fundamental operating principles of entire economies and civilizations. In first wave agrarian societies, the plow, cotton gin, tractor, combine and hybrid seed transformed production and economies. Second wave industrial societies were transformed by the internal combustion engine, electricity, electric light, Bessemer steel, mass production, and mass media. The microchip, computer and internet enabled and defined the Information Age. Currently another technology portends that a fourth paradigm shift is in its early stages of development and dissemination. This transformative technology is 3D printing or additive digital manufacturing and it is predicted that it will "up-end the last two centuries of approaches to design and manufacturing with profound geopolitical, economic, social, demographic, environmental, and security implications" (Campbell, et.al, 2011).

\section{3D Printing's First-order Impact: Versatility- It Can Fabricate Most Anything}

Digital additive manufacturing has a seemingly endless range of applications. Indeed, it is nearly impossible to identify a domain wherein 3D printing cannot be employed. From body parts for autos or humans, skin grafts or toy giraffes to tools, jewelry, guns, musical or medical instruments- if you want it you can print it. Already, there are printers large enough to print a house (Arkenberg, 2013) and others sophisticated enough to fabricate a hamburger. Admittedly, the 3D printed burger would cost ("once you factor in the bun, lettuce, and condiments") about $\$ 317,000$ (June, 2012). However, when it comes to many other everyday items that anybody would ever need or want, they now can be produced at competitive costs in one's own home or office. There currently exists a growing number of websites (such as Thingiverse, Shapeways and Ponoko) which provide free user-created digital designs for a wide range of household items, tools, gadgets, toys, hobbies and apparel that you can download and print. Thingiverse, which emerged in November 2008, has registered exponential growth in the number of available designs - growing from 25,000 in November of 2012 to 35,000 items in January 2013 to 60,000 in April, 80,000 in May and 100,000+ items by June 2013 (Howard, 2013). Paralleling the exponential growth in available applications is the commensurate growth in user downloads, with over 21 million to date. 
While the quantitative statistics are impressive there remain those skeptical of the quality of 3D printed items. As Lowry (2013) observed, "for something being touted as The Next Big Thing in manufacturing, it seems like all you can actually make are cheap plastic trinkets, like dollar store goods, only more expensive..." and not as good looking. Actual experience with the 3D printing process and product proved that even in its nascent stages the quality, convenience and cost of 3D printed products are considerable. Lowery (2013) reports:

"I've been a closet 3D printing skeptic. The 3D printing hype machine says it's going to save the economy, feed the hungry and cure cancer. ... I went digging on Thingiverse, Shapeways and Ponoko to see if there was anything I'd actually make, and what I found surprised me. Set aside art and jewelry, if you enjoy making things there are plenty of practical, every-day creations to justify the purchase. Especially when you can get a decent 3D printer for $\$ 450$. Now, having done the research, I have to swallow some of my skepticism. I'm buying a $3 \mathrm{~d}$ printer. Here are ten practical things I want to make:

1) iPhone cases... With a 3D printer, you could print a new case design every week. And there are a lot of beautiful designs out there.

2) Replacement parts.... When a small plastic part breaks, you no longer have to throw the whole product away...

3) Smartphone accessories... to get more out of your smartphone, various stands, cord wrappers, sound amplifiers and camera attachments like this cheap and effective macro lens.

4) Camera gear... From tripod mounts to lens cap holders, camera buffs can $3 D$ print inexpensive accessories made to fit their kit.

5) Bicycle accessories... A 3D printer opens up whole new opportunities. Create clips to attach to the frame, a carrying handle, or even a whole pedal.

6) Science...From a tray for washing microscope slides to custom lens mounts, you can 3D print whatever tools you need to do science...

7) Wallets and purses... you can make a great wallet or an interesting purse out of plastic... you can experiment with designs you might not buy in the store.

8) Clocks... A cheap quartz clock movement and a little 3D printing, and you have a beautiful clock. Pick from many styles.

9) Containers... around your house and you'll probably find a lot of small plastic containers. You can print those, and tailor them to their purpose, like this toothbrush holder.

10) Legos... If you are a Lego fan ... imagine printing any shape you want and just plugging it directly into the Lego universe..."

Yet, what is remarkable about 3D printing is not its ability to produce the ordinary, but rather its creation of the extraordinary. As impressive as your iPhone case or toothbrush holder may be, 3D printing is being conducted in other dimensions and on other scales that are extreme to say the least. Arkenberg (2013) reports that in the Bio/Nano/Programmable Matter lab at Autodesk Research, where they simulate atomic and molecular interactions, engineers are printing objects that can only be seen with a scanning electron microscope. Already, such 3D nanoscale printers, "which can print objects less than the width of a single human hair," are being sold commercially by Nanoscribe GmbH (Kurzweil, 2013).

Furthermore, 3-D printing is expanding its printing ink repertoire of plastics, metals and ceramics to "bioinks." Composed of hundreds of thousands of live cells, bioinks when printed, "naturally fuse to form living tissue" (Condliffe, 2013). Already, in addition to printing pharmaceuticals, dental crowns and artificial teeth, ears and breasts, 3-D printers will soon be producing human organs (Leonard, 2103). It will be as easy to produce a human leg as a toy Lego, or even a leg of lamb. 3D printing developers have already "produced prototype printed pasta, breakfast cereal and burgers to demonstrate how advances in 3D printing could transform the way we eat" (Dezeen, 2013). As a consequence of 3D printing's bio-applications it has been predicted that "by 2016, 3D printing of tissues and will cause a global debate about regulating the technology or banning it for both human and nonhuman use" (Clooney, 2013).

3D printing has reached a tipping point. It has developed to the stage of the classical disruptive technology wherein its capabilities and price points are posing a threat to established players in the field. While the moment and magnitude of impact will vary according to the nature of one's product and production processes, the time has come for every manufacturer to assess their vulnerability to and/or adoption of 3D printing technology. Faktor (2013) reports that 3D printers are already in use and impacting a wide array of industry sectors such as 
crafts, auto parts, toys, retail hardware, medical prosthetics, aircraft and industrial R\&D and prototyping. Nearing commercial use and application 3D printing will within the next few years begin to diffuse to and through prepared food, global apparel, guns \& ammo, power tools, home building \& improvement, life sciences, and science education; and within the decade begin to find commercial application in furniture manufacturing, consumer electronics and organ transplants production.

While the rate of dissemination and scope of impact will be uneven across applications (see Figure 1 below) and unpredictable across industry sectors and societies, it remains clear that $3 \mathrm{D}$ technology has emerged as the catalyst of the next industrial revolution. As Gustafson (2013) observes:

"This will not be much different than the journey computers had - from a few, big, centralized mainframes to something we now hold in our hands"... Desktop 3D printing can be done at home, the office, a hospital or a school, bringing manufacturing to non-manufacturers the way PCs brought computing to non-traditional environments... "But it's not just about replacing the technique of how we make and get a product - it's the idea that we'll be able to create brand new products, with entirely new properties, that were not possible with the old techniques... And then, any time you have new products and new properties, you're also going to change the ways business operates. You could probably take every stage in the supply chain, and if you apply it to this new world of 3D printing, the processes are going to change across the board."

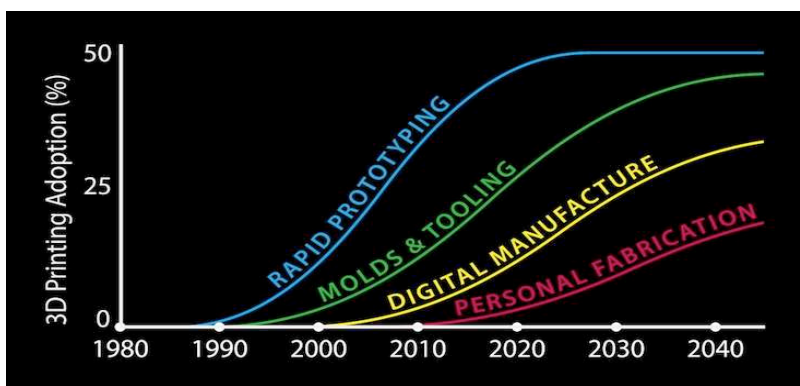

Figure 1. Diffusion adoption rate of 3D applications (Barnatt, 2013)

\section{3D Printing's Second-order of Impact: It Decimates Labor, Assembly \& Distribution Costs}

Digital additive manufacturing will render factories and the established manufacturing process obsolete as the assembly line, machine re-tooling and inventories can be eliminated and labor costs decimated.

Table 1. Traditional manufacturing vs. digital additive manufacturing

\begin{tabular}{lll}
\hline & Core Production System & Supporting System \\
\hline $\begin{array}{l}\text { Traditional } \\
\text { Manufacturing }\end{array}$ & $\begin{array}{l}\text { Use molding, assembly system for } \\
\text { parts. }\end{array}$ & $\begin{array}{l}\text { The complete supply chain which involve raw } \\
\text { materials, storage, warehouse, transportation, } \\
\text { retailing and distribution system. }\end{array}$ \\
$\begin{array}{l}\text { Digital Additive } \\
\text { Manufacturing }\end{array}$ & $\begin{array}{l}\text { Use additive system with limited or } \\
\text { Open source design, CAD design, material }\end{array}$ \\
\hline
\end{tabular}

The final product — or large pieces of a final product like a car — can be produced by AM in one process and on-demand. A given manufacturing facility would be capable of printing a huge range of types of products without retooling — and each printing could be customized without additional cost (Campbell, et al., 2011).

$3 \mathrm{D}$ printing is already very good at producing products (even with moving parts) which previously would have required the assembly of multiple components, and that by eliminating the assembly phase there will be huge savings for the manufacturer in terms of labor costs. 3D printing-based production could also reduce or eliminate storage, handling and distribution costs (McKendrick, 2012).

\section{3D Printing's Third-Order of Impact: It Is Networked, Crowd-Sourced \& Collaborative}

3D printing's disruption of the established industrial model of production and distribution is exacerbated by its intertwining with advancements in material sciences, scanner technology and CAD software with internet commerce and online collaboration, crowd-sourcing and crowd-funding. 3D printing is "more than just a tool it 
is an emerging ecosystem that is tied together through online collaboration, much of which is open source ....and enthusiasts are not only collaborating around designs but are sharing their printers as well" and thus "rapidly expanding public access to this technology" (Brody, 2013). This rapid expansion can be directly monitored and measured by the growth of websites such as Shapeways, Ponoko and Thingiverse. What Linkedin is to searching for people and Google Maps is to searching for places, Thingiverse is to searching for things, specifically things that you can print. Herein, it is now possible of most anyone to find most anything to make for and by themselves anytime anywhere. The ramifications are game changing for everyone upstream and down the supply chain and employed in the distribution and retail channels.

\section{3D Printing's Fourth-order of Impact: Its Geo-Economic Ramifications}

The fact that consumers can now print whatever item they have a need or wish for in their own home, office or neighborhood 3D printing "hub," not only renders factories obsolete but threatens whole country's economies as well. As predicted by Campbell, et al. (2011) production and distribution will be "de-globalized" as production is taken up by the consumer "designs, not products, will move around the world as digital files can be printed anywhere by any printer that can meet the design parameters... The Internet first eliminated distance as a factor in moving information and now AM eliminates it for the material world. Just as a written document can be emailed as a PDF and printed in 2D, an "STL" design file can be sent instantly to the other side of the planet via the Internet and printed in 3D."

When one combines the ability and convenience of producing one's own customized goods with the savings accrued through the elimination of labor, re-tooling, assembly, shipping and inventory carrying costs, the consequences are most ominous for any and all engaged in traditional manufacturing and dependent on the relative cost-efficiencies of out-sourcing. To the point, the first and foremost country vulnerable to 3D printings imminent disruption is China.

"As 3-D printing takes hold, the factors that have made China the workshop of the world will lose much of their force. China has grabbed outsourced-manufacturing contracts from every mature economy by pushing the mass-manufacturing model to its limit. It not only aggregates enough demand to create unprecedented efficiencies of scale but also minimizes a key cost: labor.... Under a model of widely distributed, highly flexible, small-scale manufacturing, these daunting advantages become liabilities. No workforce can be paid little enough to make up for the cost of shipping across oceans." (D'Aveni, 2013).

\section{Conclusion}

The probability that $3 \mathrm{D}$ printing could dramatically alter global production and distribution patterns is similarly posited by Campbell et al. (2011) when in the Strategic Foresight report--Could 3D Printing Change the World? - it was concluded that "manufacturing could be pulled away from manufacturing platforms like China back to the countries where the products are consumed." The result could provoke social-political unrest in exporting economies as imports shrink, so too will the need for labor and thus unemployment levels could rise to destabilizing levels.

When one considers the key attributes 3D printing: (1) its advancements and advantages in production (2) its cost and energy efficiencies in distribution (3) its versatility of application and (4) its synergy with the emergent internet and software eco-system in sum total they suggest that most certainly 3D Printing could indeed change the world. Perhaps, the real question to be addressed is not if, but rather how much and how soon will 3D printing be changing our world?

With those answers Avi Reichental (2013), president and CEO of 3D Systems, postulates that:

"In the next 5-10 years 3D printing will change everything. It will change how we print, how we create, how we manufacture, how we design, how we decorate, how we treat a variety of medical conditions... with 3D printing there are no limitations in complexity and in the final charge... the printer does not care if it prints the simplest of all geometries or the most complex one... There is no extra charge for complexity... no extra charge for minimum quantity. So whether you want to print in a quantity of one or in a quantity of one million, you can do it. That is really interesting and important for start-ups and small businesses, because all of a sudden, they can begin to access the same technology and the same capabilities that historically were reserved to big companies... at the same time if you have a computer or Internet or you can access cloud printing, you can begin to present, and design, and sell products with the same capabilities and the same technology, and the same impact that large companies have. 
That can change everything..."

\section{References}

Arkenberg, C. (2013). Cities Of The Future, Built By Drones, Bacteria, And 3-D Printers. Fast Company. Retrieved April 22, 2013, from http://www.fastcoexist.com/1681891/cities-of-the-future-built-by-drones-bacteria-and-3-d-printers

Barnatt, C. (2013). 3D Printing: The Business Opportunities. 3D Printer. Retrieved October 7, 2013, from http://www.3dprinter.net/3d-printing-the-business-opportunities

Brody, P. (2013). IBM: ELECTRONICS--Research Preview: 3D Printing Goes Exponential. Retrieved from http://on3dprinting.com/2013/03/21/ibm-sees-exponential-growth-of-3d-printing-industry/

Campbell, T., Williams, C., Ivanova, O., \& Garrett, B. (2011). Could 3D Printing Change the World? Technologies, Potential, and Implications of Additive Manufacturing. Atlantic Council. Retrieved March, 2011, from http://www.ictas.vt.edu/communication/pdf/3dprint_sfireport.pdf

Condliffe, J. (2013). A 3D-Printed Hamburger Would Cost You \$300,000. Retrieved January 21, 2013, from http://gizmodo.com/5977593/a-3d+printed-hamburger-would-cost-you-300000

Cooney, M. (2013). Gartner: Top 10 future strategic IT predictions from the impact of 3D printing to securing tons of data, Gartner lists the biggest IT challenges through 2020. Layer 8. Retrieved August 7, 2013, from http://www.networkworld.com/community/blog/gartner-top-10-future-strategic-it-predictions\#

D'Aveni, R. A. (2013). 3-D Printing Will Change the World. Harvard Business Review. Retrieved March, 2013, from http://hbr.org/2013/03/3-d-printing-will-change-the-world/

Dezeen. (2013). Food is the next frontier of $3 D$ printing. Retrieved March 27, 2013, from http://www.dezeen.com/2013/03/27/food-is-the-next-frontier-of-3d-printing-janne-kytannen/

Faktor, S. (2012). On Forbes: How HP Could Reinvent 3D Printing...and Itself. Retrieved October 15, 2012, from http://www.ideafaktory.com/technology/on-forbes-how-hp-could-reinvent-3d-printing-and-itself/

Gustafson, P. (2013). 3D Printing and the Future of Manufacturing. CSC website. Retrieved October 10, 2013, from http://www.csc.com/lef/insights/92142-3d_printing_and_the_future_of_manufacturingLeading Edge Forum Technology Program

Howard, J. (2013). The 100,000th Thing on Thingiverse! MakerBot Newsletter. Retrieved June 8, 2013, from http://www.makerbot.com/blog/2013/06/08/100000th-thing-on-thingiverse/

June, L. (2012). Scientists working on lab-grown, $\$ 300,000$ hamburger. The Verge. Retrieved February 20, 2012, from $\mathrm{http}: / / \mathrm{www}$.theverge.com/2012/2/20/2811553/scientists-working-to-produce-a

Kurzweil. (2013). Microscopic 3D printing. Kurzweil News. Retrieved February 11, 2013, from http://www.kurzweilai.net/microscopic-3d-printing

Leonard, A. (2013). Is there anything 3-D printing can't do? Retrieved March 25, 2013, from http://www.salon.com/2013/03/25/is_there_anything_3d_printing_cant_do/?utm_source=twitterfeed\&utm _ medium=twitter

Lowry, E. (2013). Ten Practical Things to Make with a 3D Printer. Hack Things. Retrieved April 12, 2013, from http://www.hackthings.com/ten-practical-things-to-make-with-a-3d-printer/

McKendrick, J. (2012). 3D printing may put global supply chains out of business. SmartPlanet Blog. Retrieved October 9, 2012, from http://www.smartplanet.com/blog/bulletin/3d-printing-may-put-global-supply-chains-out-of-business-report $/ 2019$

Reichental, A. (2013). Interview: Avi Reichental on the 3D Printing Revolution. Huffington Post. Retrieved March 27, 2013 from http://www.huffingtonpost.com/lilia-ziamou/avi-reichental-3d-printing_b_2944886

\section{Copyrights}

Copyright for this article is retained by the author(s), with first publication rights granted to the journal.

This is an open-access article distributed under the terms and conditions of the Creative Commons Attribution license (http://creativecommons.org/licenses/by/3.0/). 